\title{
2. BIOGENIC SEDIMENTARY STRUCTURES IN OUTER BENGAL FAN DEPOSITS DRILLED DURING LEG 116 ${ }^{1}$
}

\author{
Andreas Wetzel ${ }^{2.3}$ and N. P. Wijayananda ${ }^{4}$
}

\begin{abstract}
Bioturbation in the outer Bengal Fan is influenced by two major factors, bottom-water oxygenation and turbidite deposition. Biogenic traces reflect changing bottom-water oxygenation over the last $17 \mathrm{~m} . \mathrm{y} . ;$ in the Miocene clear oxygenation cycles are developed in the hemipelagically deposited sections. Since the Pliocene these cycles are less pronounced and an intermediate level of oxygenation is documented by the trace fossils. As only three closely spaced sections were studied, it is uncertain whether the change in oxygenation is a regional phenomenon or just a local effect resulting from changing bottom topography due to intraplate deformation.

Turbidite deposition also strongly influences bioturbation at the sites studied. In the outer Bengal Fan, fine-grained parts of turbidites are often burrowed. In contrast, biogenic reworking is less intense or nonexistent in the sandy parts of turbidites. A considerable number of the fine-grained sections are bioturbated by Phycospiphon, and the thickness of the reworked section can exceed the penetration depth of this trace. In this case, we infer that bioturbation and sediment accumulation were in equilibrium and that sedimentation was relatively slow for normal deposition by a turbidity current of the order of $1 \mathrm{~cm}$ per day during an event.
\end{abstract}

\section{INTRODUCTION}

During the last few decades the analysis of biogenic sedimentary structures has proven to be a valuable tool for the characterization of environmental conditions (e.g., Seilacher, 1953, 1967; Schäfer, 1956; Frey, 1975; Basan, 1978; Ekdale et al., 1984). In deep-sea sediments especially, trace fossils document the paleoecology and geologic history of the benthic macro-organisms that are not normally preserved in the fossil record as body fossils.

This is also the case in the sediments studied here; fossil remains are sparse to absent due to dilution of the concentration of fossils by high sedimentation rates and dissolution of most of the calcareous as well as siliceous microfossils (see Cochran, Stow, et al., 1989). Thus, trace fossils can provide valuable information concerning the environmental situation and how it has changed in the outer Bengal Fan for the last 17 $\mathrm{m} . \mathrm{y}$. This information is presented here.

\section{AREA OF INVESTIGATION}

The outer Bengal Fan deposits investigated in this study were drilled during Ocean Driliing Program (ODP) Leg 116 at three sites about $800 \mathrm{~km}$ south of Sri Lanka in 4700 to $4750 \mathrm{~m}$ water depth (Fig. 1). The sediments were mainly deposited by turbidity currents originating from the Ganges Brahmaputra Delta (gray sandy, silty turbidites), the adjacent shelf (dark gray silty to muddy turbidites), and more local shelf or seamount source (green pelagic turbidites) (Stow et al., this volume). Pelagic intervals also occur at the tops of turbidites. The main lithologic units are given in Figure 2. At all three sites, sediments of similar composition and lithology were found; they differ only in the thickness of the defined lithologic units (Fig. 2). Sedimentation is dominated by turbidites for

\footnotetext{
${ }^{1}$ Cochran, J. R., Stow, D.A.V., et al., 1990. Proc. ODP, Sci. Results, 116: College Station, TX (Ocean Drilling Program).

${ }^{2}$ Geologisch-Paläontologisches Institut der Universität, Sigwartstra $\beta$ e 10 D 7400 Tübingen, Federal Republic of Germany.

${ }^{3}$ Present address: Geologisch-Paläontologisches Institut der Universität, Bernoullistra $\beta$ e $32 \mathrm{CH} 4056$ Basel, Switzerland.

${ }^{4}$ National Aquatic Resources Agency, Oceanographic Unit, Crow Island, Mattakkuliya, Colombo 15, Sri Lanka.
}

which an average frequency of $>500 \mathrm{yr} /$ event was calculated (Stow et al., this volume). The sedimentation rate is on average 20-30 cm/k.y. (see Cochran, Stow, et al., 1989).

\section{METHODS}

Biogenic sedimentary structures were mainly studied visually on the freshly cut cores. In addition, some homogeneous or heavily bioturbated sections as well as those containing some specific traces were X-rayed to get maximum information. For this procedure 5-to-10-mm thick slabs were cut from the required sections (e.g., Werner, 1967).

The trace fossils were identified in typical cross-section. Because such identification may be subjective, they were defined only at the ichnogenus level (Häntzschel, 1965, 1975).

In general, two types of biogenic sedimentary structures can be distinguished: (1) trace fossils with a well-defined shape and sharp, distinct outlines (Fig. 3) and (2) biodeformational structures having indistinct outlines and features and which destroy pre-existing structures. Only trace fossils are discussed here.

\section{RESULTS \\ Description of Trace Fossils}

\section{Chondrites}

Chondrites are three-dimensional burrow systems that normally branch downward into the sediment at angles of $30^{\circ}-60^{\circ}$. They are simple tunnels or wall-lined tubes (Wetzel, 1981) that consist of a connection to the seafloor and a typically branched lower part. In general, tunnels become more horizontal with depth below the surface of the seafloor (Fig. 3). Different types were identified in the sediments drilled during Leg 116 by their differing diameter and sediment fill, as suggested by Wetzel (1981). The Chondrites-producing organism has also reworked other biogenic structures forming composite burrows.

\section{Phycosiphon}

Phycosiphon is a compound antler-like spreiten that consists of small U-shaped inclined parts mostly oblique to the 


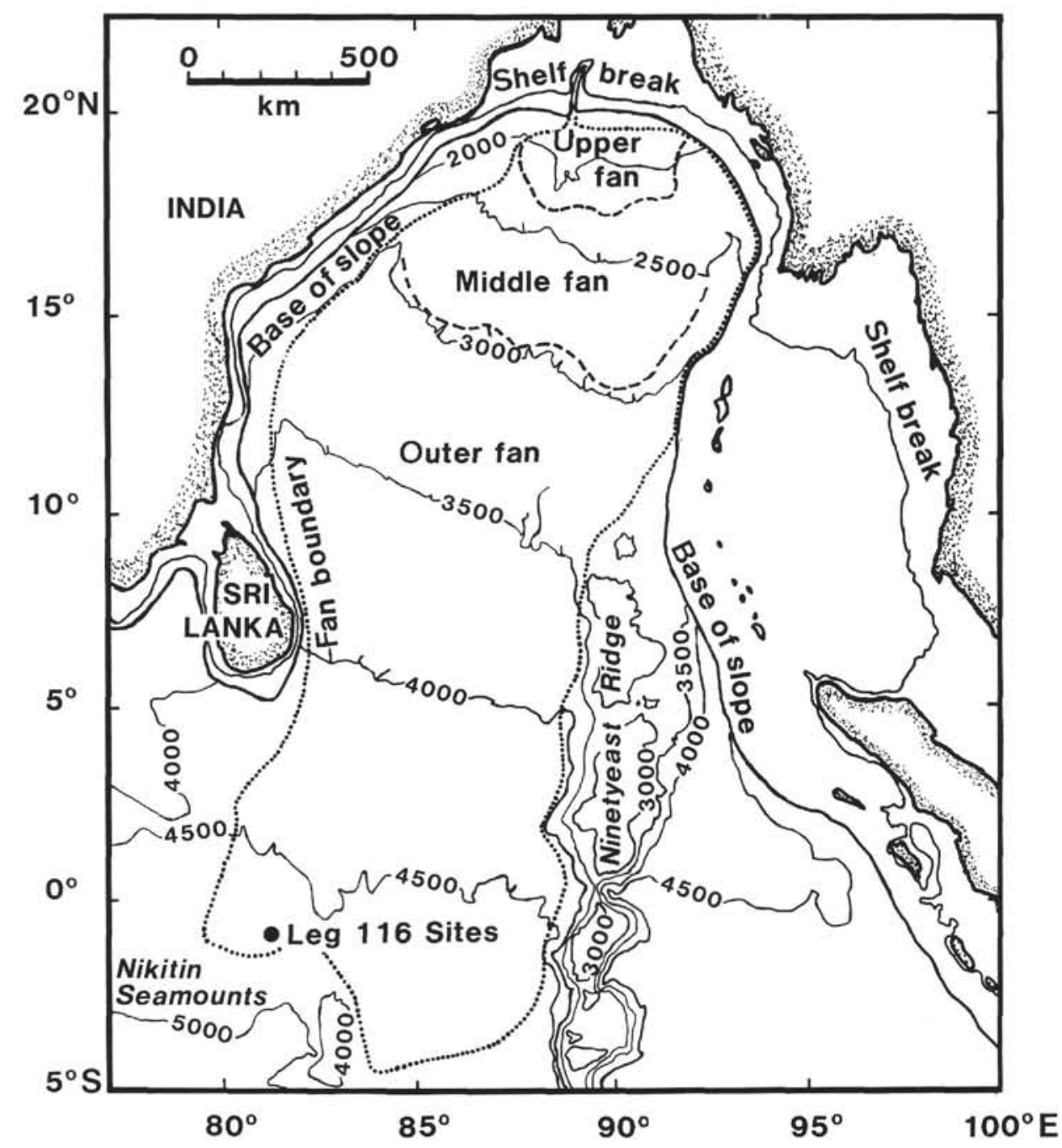

Figure 1. Map of Leg 116 study area. Depth contours are in meters.

bedding (Figs. 3 and 4). The width of the spreiten is $1-5 \mathrm{~mm}$, the diameter of the marginal tube $0.5-1 \mathrm{~mm}$. The marginal tubes show a thin lining.

However, in case of high burrow density Phycosiphon cannot always be determined with certainty in vertical sections because Phycosiphon, Anconichnus (Kern, 1978), Helminthoida (Chamberlain, 1978), or Chondrites-like burrows (Ekdale and Bromley, 1984) show similar cross-sections. Nevertheless, detailed observations on the Bengal Fan deposits justify the classification of these burrows as Phycosiphon. Three points are of importance.

1. The presence of spreiten is clearly indicated by the reworked sediment between two tubes (careful examination of Figs. 4B and 4C); the reworked sediment is lighter colored. The existence of a spreiten excludes a classification as $\mathrm{Hel}$ minthoida or Chondrites-like burrows.

2. A branching of the spreiten was observed (Fig. 4C); this is typical for Phycosiphon, but not known from Anconichnus (Kern, 1978).

3. In the outer Bengal Fan sediments, Phycosiphon penetrate deeper than $10 \mathrm{~cm}$; such burrowing behavior is not known from Helminthoida or Anconichnus.

\section{Planolites}

Planolites is normally unbranched, straight, or gently curved, cylindrical, and more or less horizontal. Active filling of the burrow is indicated by (1) grain-size differences with the surrounding sediment and (2) relatively close packing of infill. The latter point was deduced from the fact that no differential compaction occurs between Planolites and other actively filled burrows, e.g., Chondrites (Wetzel, 1987). The active fill is a major criterion (Pemberton and Frey, 1982) and, hence, these burrows were grouped into the ichnogenus Planolites.

\section{Skolithos}

Skolithos is a simple, vertical shaft of a uniform diameter, varying between 2 and $5 \mathrm{~mm}$ (Figs. 3 and 4).

\section{Thalassinoides}

Thalassinoides is composed of cylindrical tubes that branch to form a three-dimensional, more or less horizontal network connected to the seafloor by sub-vertical or vertical shafts. Typical swellings at the bases of branches or elsewhere are observed (Fig. 3). A typical asymmetrical (eccentric) fill structure often results from active filling by the burrowing organism or collapse of the burrow walls. The tubes are 5-20 $\mathrm{mm}$ in diameter. 


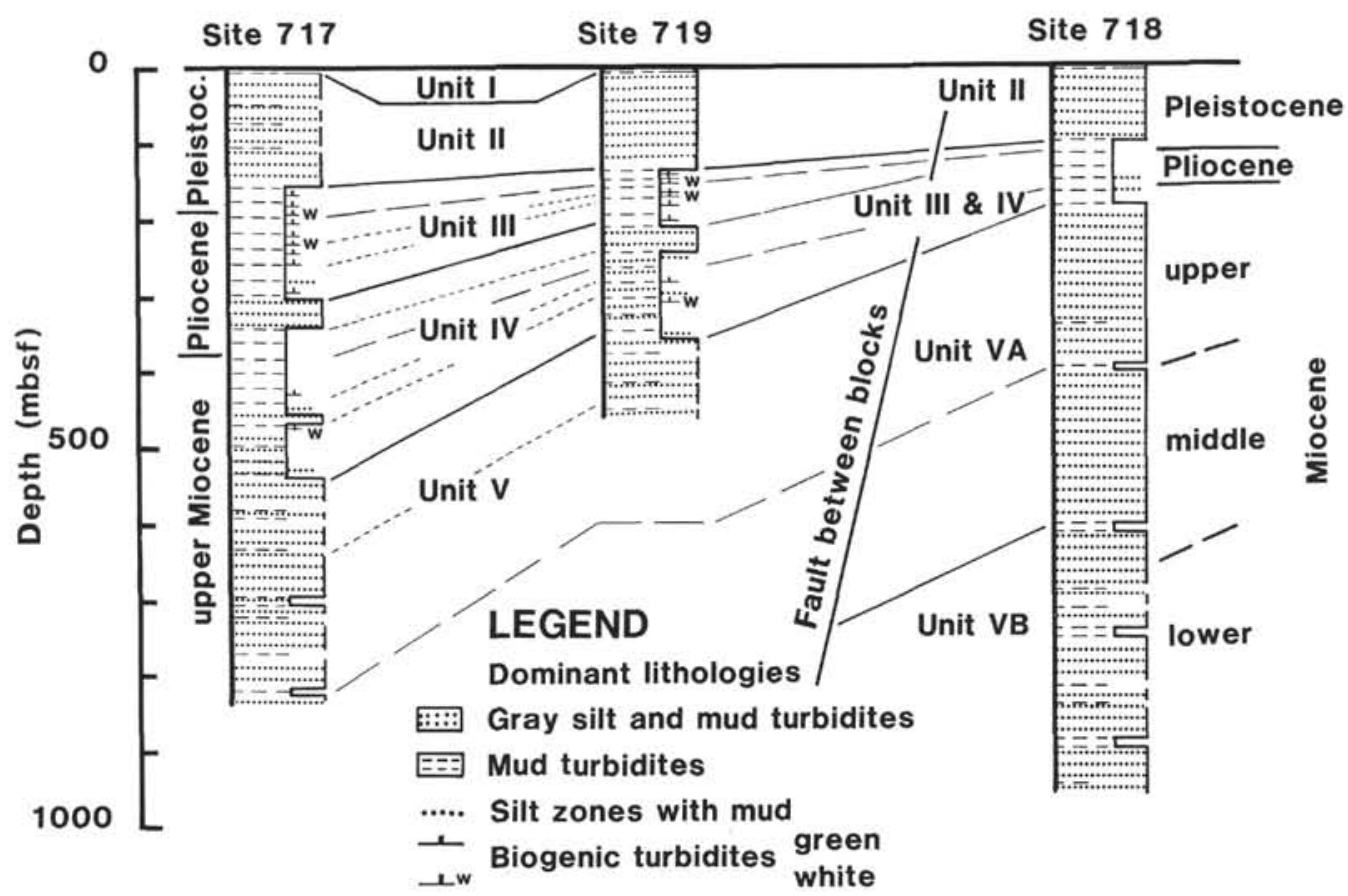

Figure 2. Major lithologic units as defined from the drilled sites.

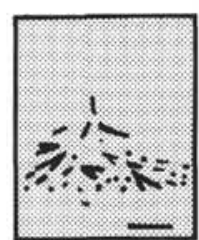

Chondrites

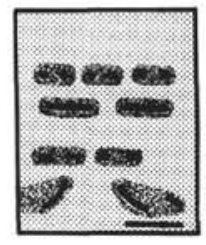

Phycosiphon
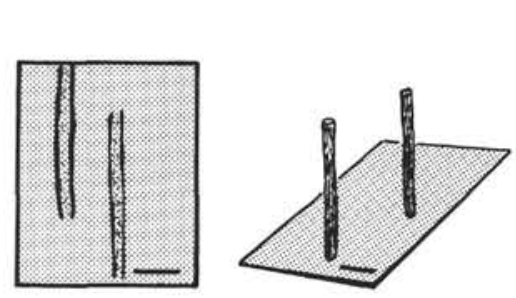

Skolithos
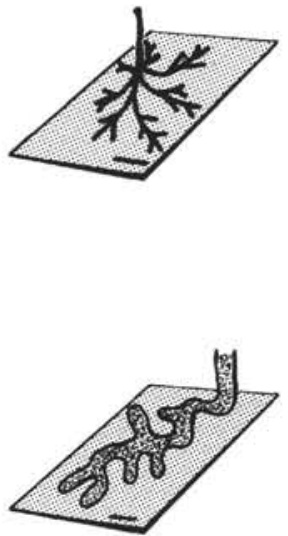
Figure 3. Trace fossils observed in the outer Bengal Fan de
$1 \mathrm{~cm}$. Characteristics of the burrows are described in text.
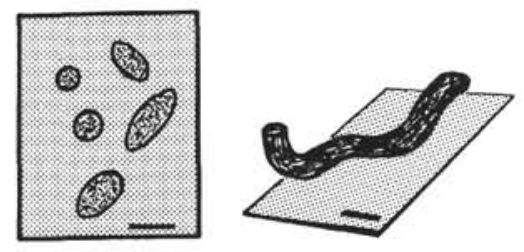

Planolites
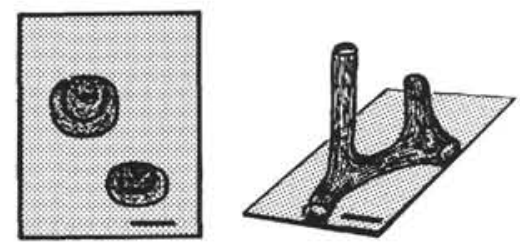

Thalassinoides
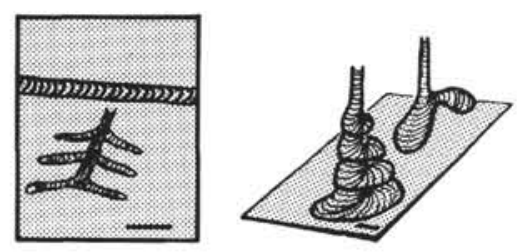

Zoophycos 


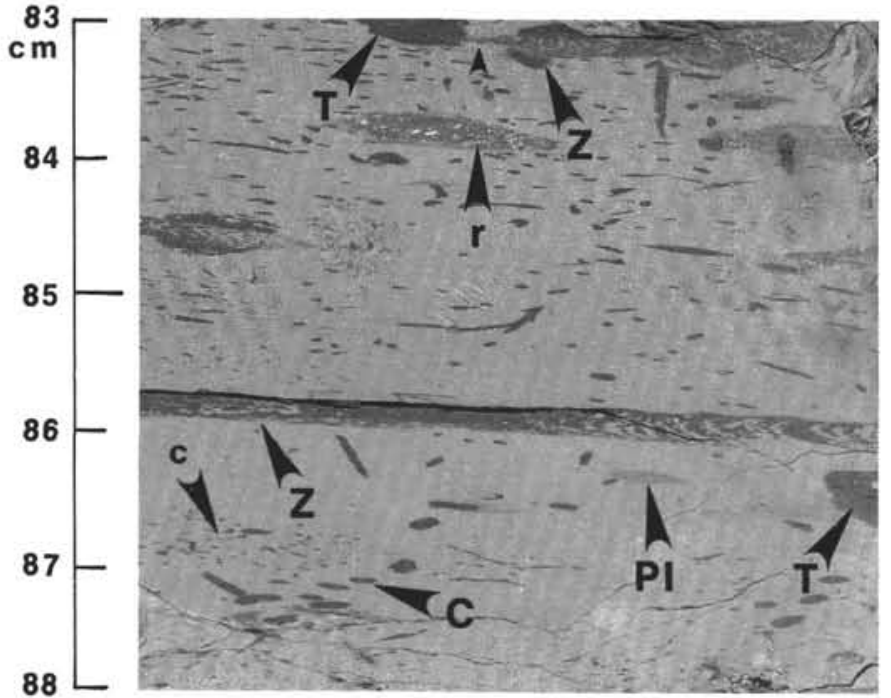

A
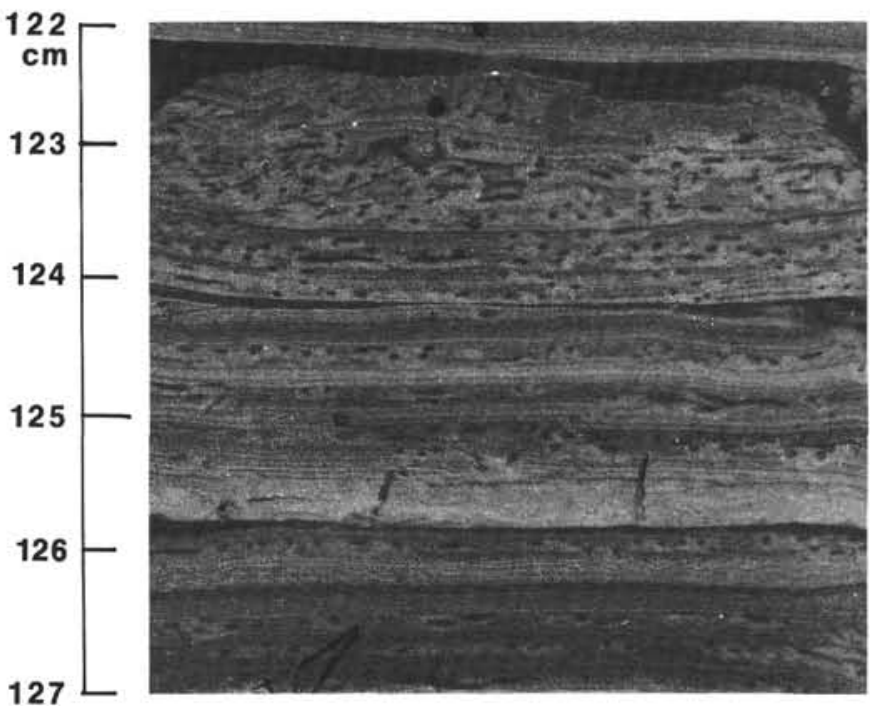

B

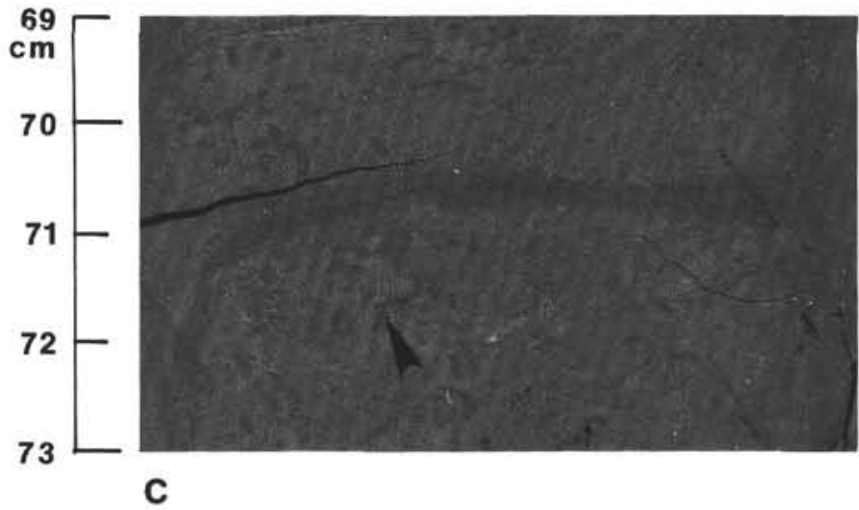

Figure 4. Photographs of trace fossils in outer Bengal Fan deposits. A. Sample 116-718C-72-5, 83-88 cm, containing different types of Chondrites $(\mathrm{C}, \mathrm{c}$; note different diameters), Planolites $(P l)$, Planolites reworked by Chondrites $(\mathrm{r})$, Thalassinoides $(T)$, Zoophycos $(Z)$ with previously open marginal tube (now compressed due to compaction. Note cross-cutting relationships between burrows. B. Sample 116-718C-78-5, 122-127 cm., Phycosiphon, note paired tubes with typical reworked halo around and between them. C. Sample 116-717C-26-6, 69-73 cm., Phycosiphon spreiten.

\section{Zoophycos}

Zoophycos is composed of horizontal to oblique-feeding spreiten that surround the nearly vertical central shaft of the burrow in distinct levels or spirals (Figs. 3 and 4). In crosssection the spreiten often exhibit regular, crescentic structures. The spreiten may vary in thickness between 1 and 7 $\mathrm{mm}$. Zoophycos can have two types of marginal tubes.

1. Open marginal tubes belong to a $\mathrm{U}$-shaped open system with two openings at the seafloor allowing efficient, continuous ventilation of the burrows. Open marginal tubes are preferably found in environments with high organic matter content of the sediment and/or low oxygen content of the bottom water (Wetzel and Werner, 1981).

2. Filled marginal tubes belong to J-shaped open-tube systems with only one opening at the seafloor. Zoophycos with filled marginal tubes are often found in oxic environments (Wetzel and Werner, 1981).

\section{Distribution and Interpretation of Biogenic Structures}

The type and frequency of the biogenic structures observed in the sediments retrieved during Leg 116 are shown in Figure 5.

Generally, bioturbation in the sediments is greatly variable. To interpret the different bioturbation patterns, it is essential to consider the arrangement of burrows within the bioturbated zone. Four dynamic environmental situations were distinguished: (1) steadystate, (2) enhanced sediment accumulation, (3) fluctuating oxygenation, and (4) nonbioturbated.

\section{Steady-state Conditions}

The first case represents the situation as it occurs under steady-state, hemipelagic conditions, as is found above the turbidites (Fig. 6), and similar to the bioturbational pattern found in modern (hemi)pelagic surface sediments in the deep sea (e.g., Berger et al., 1979, Wetzel, 1981).

A certain vertical succession of the biogenic sedimentary structures can be deduced from the penetration depth and the 

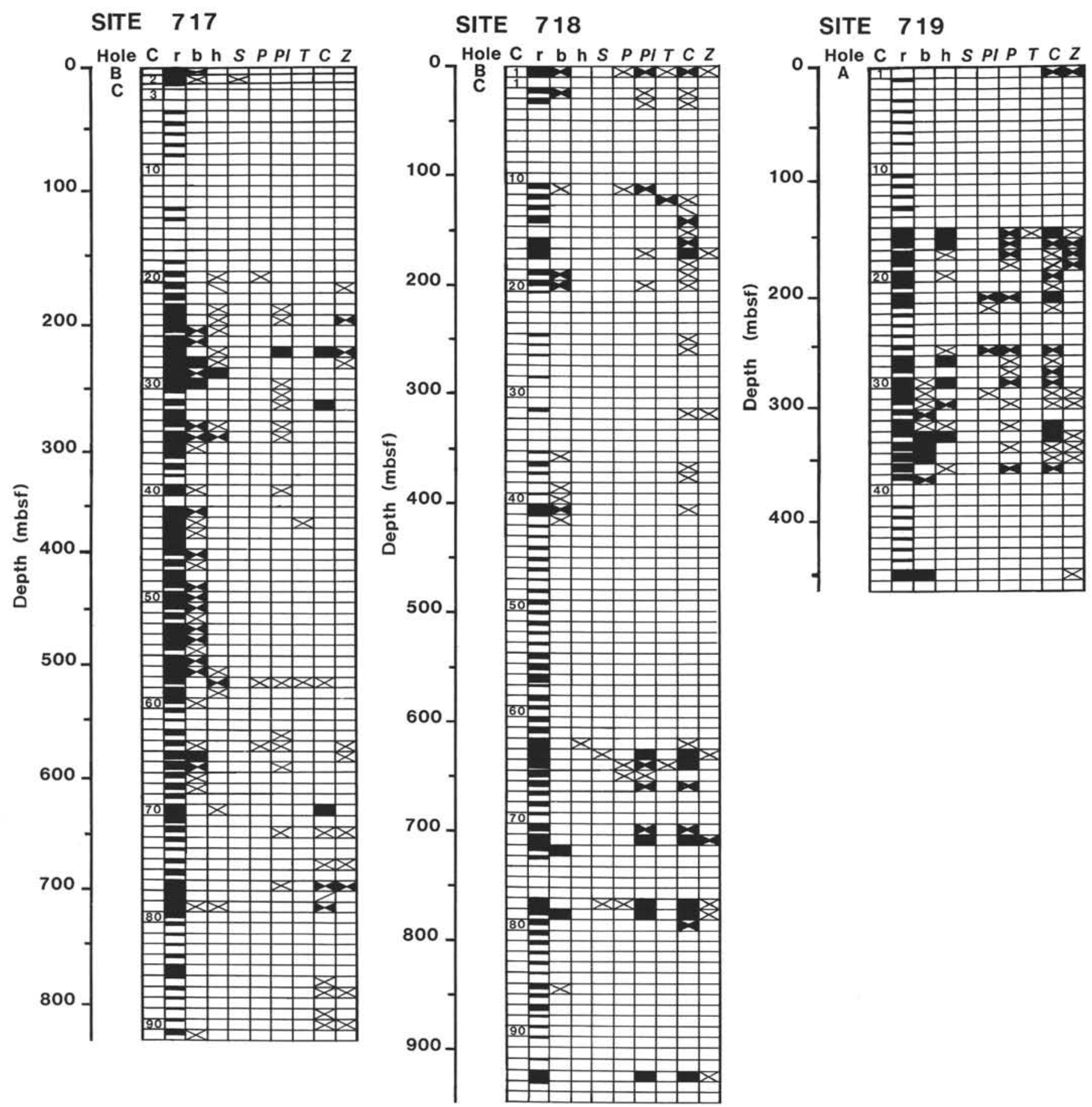

Figure 5. Occurrence and frequency of biogenic sedimentary structures observed in the recovered outer Bengal Fan deposits. Abbreviations as follows. Roman letters: C, core number; $r$, recovered sections (black); $b$, undefined burrows (mainly due to core disturbance or low visual contrast); h, homogeneous layer (referring to tier I). Italics: S, Skolithos; P, Phycosiphon; Pl, Planolites; T, Thalassinoides; C, Chondrites; Z, Zoophycos. Signature: black, dominant; two dark triangles, frequent; cross, subordinate.

relative age of the burrows, which can be derived from their cross-cutting relationships (e.g., Wetzel, 1981, 1984, Bromley and Ekdale, 1986, Savrda and Bottjer, 1986); the deeper an organism burrows into the sediment, the higher is its potential for cross-cutting previously formed biogenic traces. In principal, the cross-cut burrows were made at a shallower depth than the intersecting ones. Traces cross-cutting each other at nearly equal frequencies have nearly the same penetration depth, and hence they define a certain depth level within the bioturbated zone, a so-called tier. In this way, five tiers were distinguished in the investigated sediments (Fig. 7): (1) an uppermost homogeneous layer resulting from surface-grazing organisms (often less than $1 \mathrm{~cm}$ in thickness); (2) Phycosiphon $(<5-10 \mathrm{~cm})$; (3) Planolites $(<10 \mathrm{~cm}) ;$ (4) Chondrites $(<15 \mathrm{~cm})$; and (5) Zoophycos $(<20 \mathrm{~cm})$.

\section{Enhanced Sediment Accumulation}

The second case shows a sequence of tiers that is out of order. Tier (1) with a homogeneous structure or tier (2) containing Phycosiphon occur predominantly above a basal 


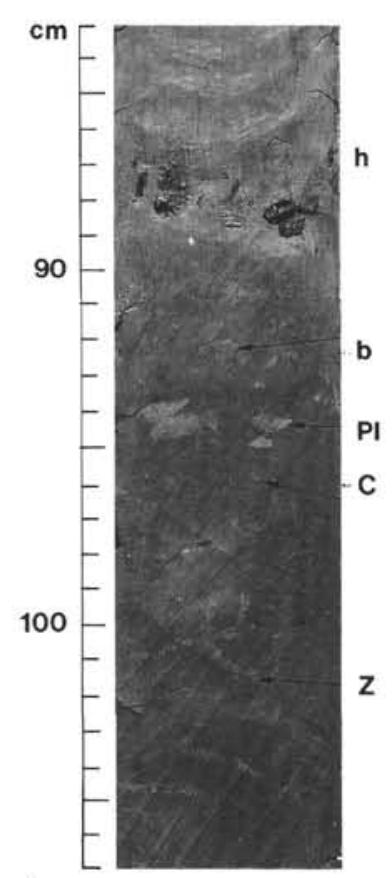

A

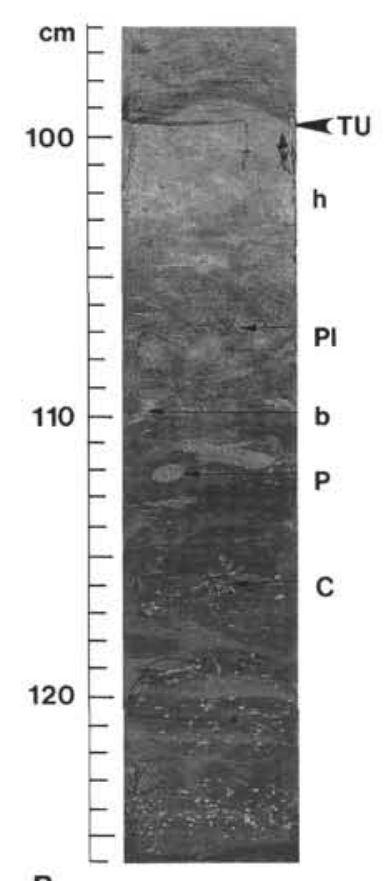

B

Figure 6. Vertical arrangement of burrows in the bioturbated zone in hemipelagic outer Bengal Fan deposits. A. Sample 116-717C-28-2, 83-107 cm; below a homogeneous layer (h) undefined burrows (b), Planolites $(P l)$, poorly visible Chondrites $(C)$, and Zoophycos (Z) occur. B. Sample 116-717C-53-6, 96-126 cm; base of mud turbidite $(\mathrm{B})$, homogeneous layer (tier 1) (h), Phycosiphon $(P)$, undefined burrows (b), Planolites ( $P l)$, Chondrites $(C)$, base of a turbidite (TU). The observed vertical succession allows tiers to be established.

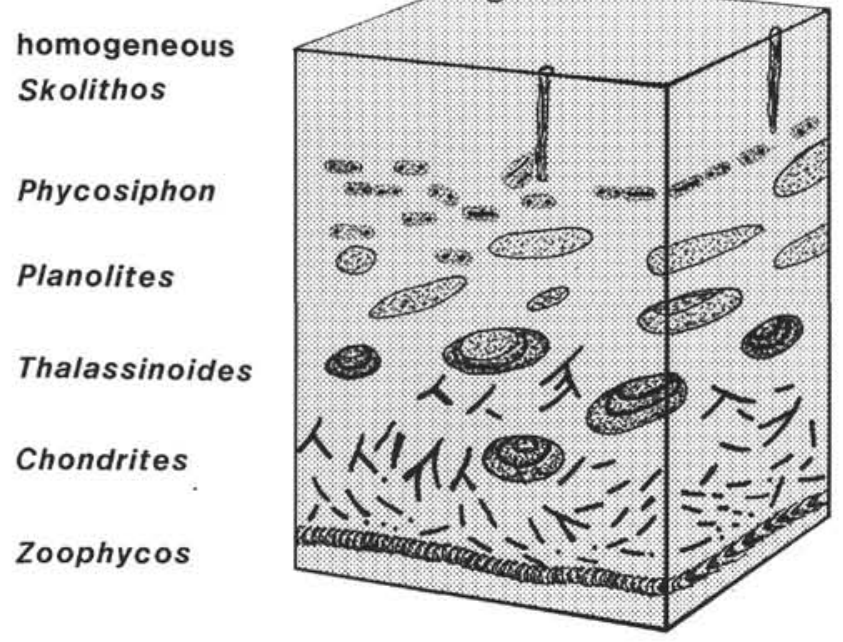

Figure 7. Vertical zonation of burrows under steady-state hemipelagic conditions. A tiering structure of five levels is typical.

section of varying thickness containing primary sedimentary structures representing deposition from a turbidity current (Fig. 8). Further upcore, the normal tiering structure, tiers (5) to (1), is observed whereby tier (1) is preserved below the base of the next turbidite. The lack of a sharp boundary between the middle section, often containing Phycosiphon and the normal tiering structure where Phycosiphon is penetrated by other traces, indicates more or less continuous bioturbation. A slight grading of grain size can still be observed within the bioturbated part (see Stow et al., this volume).

This pattern of emplacement of biogenic sedimentary structures can be best interpreted by considering the ecologic factors that disturb a tiered zonation of animals. Under steady-state conditions the upper tiers are normally overprinted by the succeeding deeper ones as the bioturbated zone moves upward due to sedimentation. Therefore, the preservation of a shallow tier (here, tier (2)) is due to a reduction of the burrowing activity in the lower tiers. Thus, animal distribution within the seafloor is the most important factor in evaluating which environmental change is responsible for such a disturbance of the "normal" tiered bioturbation pattern.

Deep-sea infaunal organisms are patchily distributed on and within the seafloor (e.g., Jumars and Ekman, 1983). Therefore, a certain time interval is required to bioturbate the sediments evenly within a larger area by a certain ichnogenus. Thus, population density of animals and the time required for bioturbation are inversely related to each other. Furthermore, the deeper the animals are living within the deposits, the less dense is their population on average because the benthic food content decreases with increasing depth in sediment (e.g., Thiel, 1975, 1983). Thus, the time necessary to obtain significant bioturbation within a specific deeper tier also increases with the penetration depth of the burrowing organisms.

The scheme outlined above may explain our observations. With increasing sedimentation rate bioturbation becomes less intense to absent, first in the deepest tier where the animal density is lowest and then successively in the shallower tiers. The preservation of the shallow Phycosiphon tier in the Bengal Fan sediments can therefore be ascribed to an increase in sedimentation rate. A decrease in sediment accumulation then results in the establishment of the normal tiering structure. However, if the sedimentation rate also exceeds the bioturbation rate in the upper tier, primary sedimentary structures may be preserved.

On the other hand, in areas where there is a patchy distribution of fauna within one tier, bioturbation appears to be unaffected by the increase in sedimentation rate. This situation has been documented by Wetzel (1981) in a comparison of samples taken adjacent to each other that revealed significant differences in the bioturbation intensity.

Other environmental changes can be excluded as possible reasons for this specific bioturbation pattern in turbidites for the following reasons.

1. Oxygenation. In oxygen-depleted environments with increasing or decreasing oxygen availability, the trace fossils appear or disappear in a certain order in the fossil record (e.g., Wetzel, 1981, Bromley and Ekdale, 1984, Sarvda and Bottjer, 1986). This differs markedly, however, from the cases observed (see below).

2. Fluctuations in benthic food content. Variations in the organic matter content within turbidites are small according to shipboard data from Leg 116; hence, fluctuations of benthic food can be excluded as a possible reason for the observed bioturbation phenomena.

3. Variations in grain size. Normally, Phycosiphon is adapted to a turbiditic environment (e.g., Seilacher, 1962, Wetzel, 1984), and hence it is not too sensitive against changes in grain size in the sections studied.

Consequently, in context with the observed grading of grain size, this specific arrangement of the biogenic sedimen- 


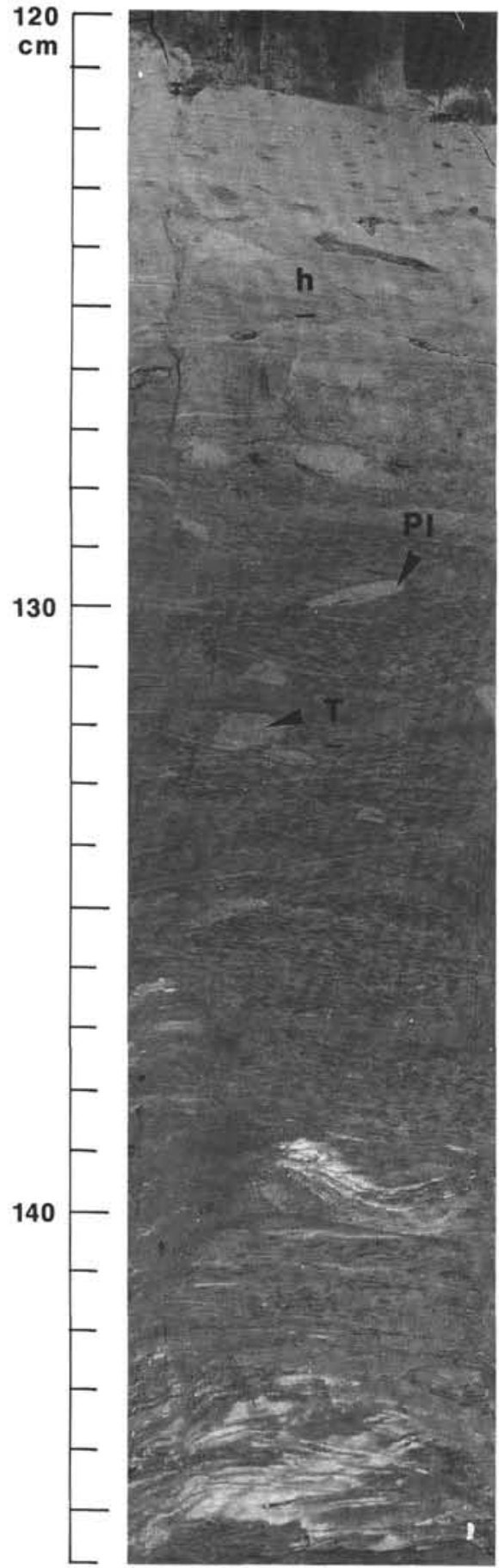

A

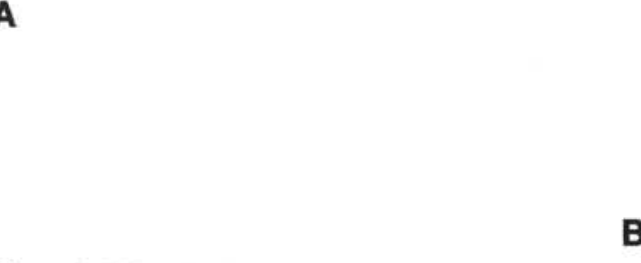

Figure 8. Bioturbation under conditions of enhanced sediment accumulation; the fine-grained part of a turbidite is typically bioturbated by Phycosiphon. The thickness of the graded and bioturbated section exceeds the penetration depth of Phycosiphon. Thus, biogenic reworking and sediment accumulation should be in equilibrium for a certain time. Consequently, this pattern indicates relatively slow sediment accumulation from a turbidite suspension cloud. A. Sample 116-717C-57-6, 120-146 cm; the interval bioturbated by Phycosiphon (not marked) measures, in the compacted state, 12 $\mathrm{cm}$, after turbidite deposition the normal tiering structure is re-established with Thalassinoides $(T)$, Planolites Pl, and the homogeneous layer (h). B. Close-up of a 16-cm-long interval bioturbated by Phycosiphon within a fine-grained, graded turbidite from Sample 116-718C-11-3, 12-28 cm.

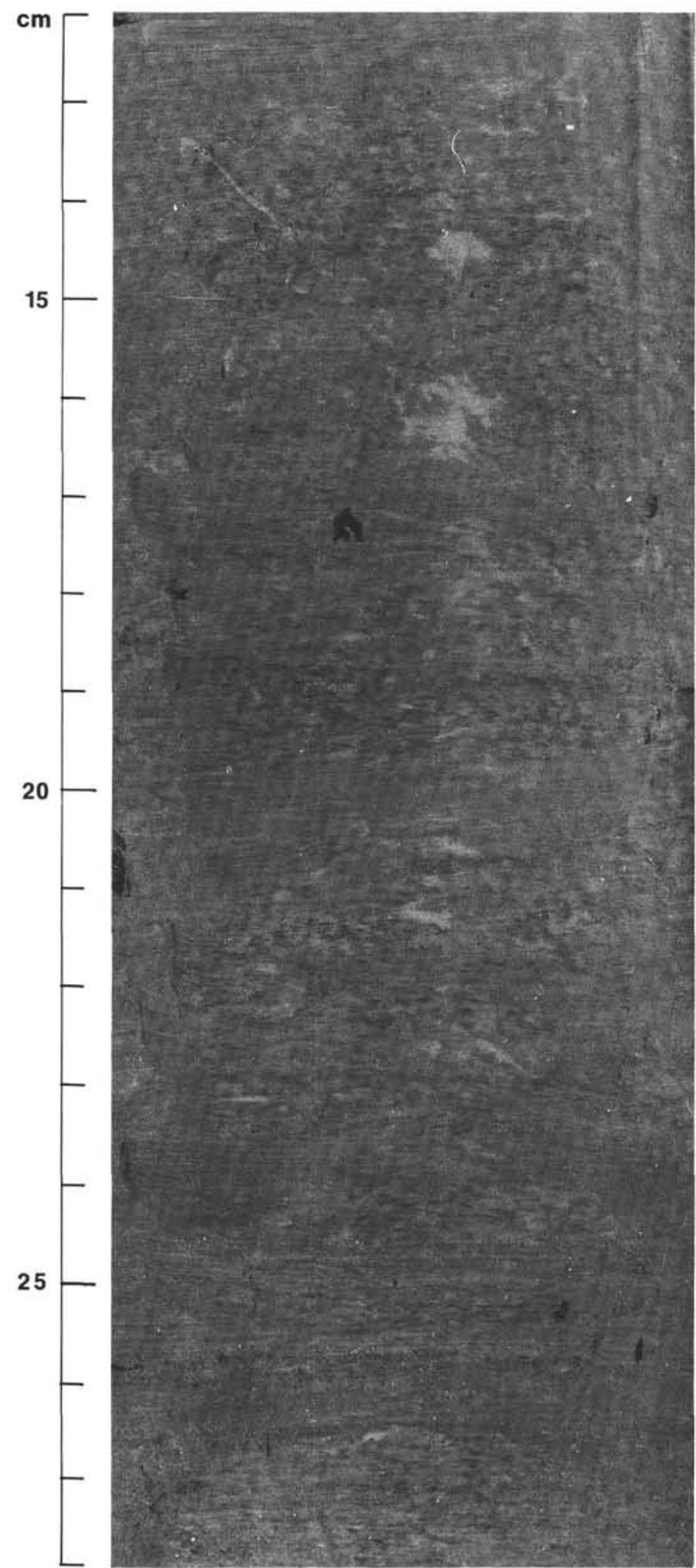

B 
tary structures is interpreted to result from variations in sedimentation rate due to deposition from turbidity currents.

\section{Fluctuating Oxygenation}

This case is frequently preserved in the normally ungraded, hemipelagic background sediments. They are characterized by (1) variations in the penetration depth of trace fossils and (2) changing diameter of burrows. The changes in the bioturbation pattern correlate roughly with the sediment color. However, sediment color is certainly not an indicator for oxygenation within the benthic boundary layer (e.g., Ekdale, 1985), but it was useful in the cores we studied for a first, rough approximation when only two categories were distinguished. These categories were (1) red- or brown-colored, i.e., containing iron in the oxidized state, and (2) gray, green to black colored sediments with iron in the reduced state.

Dark sediments (gray to black) are characterized by a shallower penetration depth of organisms than are lighter sediments. Burrowing depth can sometimes be directly determined below laminated dark-green to black sediments. The decrease in penetration depth coincides with a definite disappearance succession of specific traces; Planolites are followed by Chondrites (Fig. 9). Such a bioturbation pattern was interpreted by Savrda and Bottjer (1986) as resulting from decreasing oxygen availability in the respiration water. Typical for low oxygen content are also small-sized Zoophycos (Marintsch and Finks, 1978) that often have a U-shaped marginal tube (Wetzel and Werner, 1981), and in an even more oxygen-depleted environment Chondrites (Bromley and Ekdale, 1984). In contrast, the red/brown-colored sediments are normally bioturbated by relatively large-sized, shallowpenetrating, burrows and a condensed ("telescoped") succession of the whole burrow assemblage. Such a pattern is typical for oxidized, slowly accumulating deposits (Werner and Wetzel, 1982; Wetzel, 1983). Most of the organic compounds (referrring to potential food source) are decomposed on the sediment surface during their long exposure time. Consequently, deeper within the sediments benthic food is scarce, thus restricting bioturbation to the upper sediment layer.

The changes in oxygenation within the sediment may be due to changing oxygen content of bottom water because most of the observed burrows maintain an open connection to the seafloor.

The succession of burrows in the more or less oxidized intervals is similar to that described by Savrda and Bottjer (1986), Werner and Wetzel (1982), and Wetzel (1983) and it suggests changing bottom-water oxygenation as a reason for the observed ichnofaunal changes.

In summary, Miocene sediments document markedly fluctuating oxygen conditions. However, upsection the differences between well-oxygenated and less-oxygenated intervals become less obvious. Since the Pliocene a situation has been reached that has an ichnofabric typical of sediments where the oxygen content of the bottom water is $>3 \mathrm{~cm}^{3} \mathrm{O}_{2}$ per liter (Wetzel, 1983). This is in accordance with the observed oxygen concentration in the bottom water of the Indian Ocean in this region $\left(4 \mathrm{~cm}^{3} \mathrm{O}_{2}\right.$ per liter, Wyrtki, 1971).

It is not clear from the three sections drilled whether this variable oxygenation is a phenomenon due to regional environmental changes or just a local effect that is related to the changing seafloor morphology due to intraplate deformation. However, the seafloor morphology tends to be smooth and, hence it is assumed that global changes are documented.

\section{Nonbioturbated Sediments}

In the studied sediments, biogenic reworking is restricted or absent typically in rapidly deposited sandy, silty, and, in some cases, fine-grained graded, turbiditic deposits.

The absence of bioturbation in coarse-grained parts of turbidites may be due to two main factors. First, the deposits accumulated too rapidly to become reworked by organisms (see above). Second, the seldomly occurring sandy to silty turbidite events (on average 1 per $500 \mathrm{yr}$, see Stow et al., this volume) drastically change the substrate. These sediments cannot be bioturbated by benthic infauna because the deepsea infaunal organims require a long-term adaptation to their environment (e.g., Seilacher, 1977), and they are, therefore, unable to burrow rare-event deposits that behave mechanically very differently.

Fine-grained turbidites are normally not bioturbated when the accumulation rate of sediments markedly exceeds the reworking rate by organisms. In this case the patchily distributed fauna cannot compensate for the rapid deposition (see above). Typical sedimentary structures (Stow and Piper, 1984) were used to identify muddy turbidites, and when such structures were lacking the gradation of physical properties was used (see Stow et al., this volume).

Furthermore, bioturbation is also absent in anoxic, hemipelagic deposits. A particular succession in the disappearance of burrows is often found below such sections (see above).

\section{CONCLUSIONS}

1. The outer Bengal Fan deposits drilled during Leg 116 are bioturbated to varying degrees. Generally, biogenic structures occur in most intervals, but bioturbation is often not intense. Especially in the sandy and silty turbiditic sediments, burrows are rare to absent because of rapid sedimentation and a drastic change in grain-size spectrum.

2. In the slowly accumulated hemipelagic deposits that represent steady-state hemipelagic conditions, a certain vertical zonation of burrows (tiering) was observed that is similar to the succession found in modern surface sediments. Five tiers could be distinguished on the basis of the normal depth of burrowing of certain trace fossils; these were characterized from top to bottom as structureless ichnofabric, Phycosiphon, Planolites, Chondrites, and Zoophycos.

3. Environmental variations are indicated by a different vertical sequence and changing size of burrows when compared with steady-state conditions. Four cases were distinguished: (1) steady-state conditions; (2) enhanced sediment accumulation leading to the preservation of shallower tiers (mainly Phycosiphon), normally found between turbidite bases and hemipelagic deposits; (3) changes in the oxygenation of the bottom water as indicated by the telescoping of the bioturbated zone when $\mathrm{O}_{2}$ increases and a certain disappearance order of the burrows when oxygen decreases; and (4) nonbioturbation, due to either very rapid sediment accumulation or oxygen depletion.

4. Biogenic structures document variations in bottomwater oxygenation: (a) the Miocene hemipelagic deposits clearly show oxygenation cycles and (b) since the Pliocene these cycles are less pronounced, and a relatively low level of bottom-water oxygenation is indicated by the trace fossil community. Comparisons with similar ichnocoenoses from modern sediments indicate an oxygen content of from $>1$ to 5 $\mathrm{cm}^{3} \mathrm{O}_{2}$ per liter, which is in good agreement with the values observed in the present-day Bay of Bengal. 

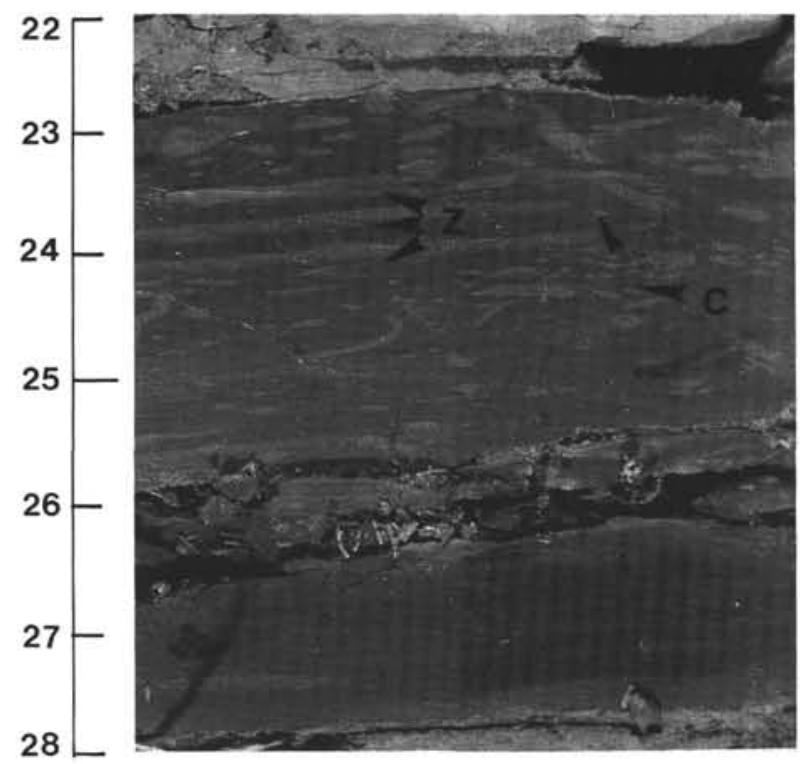

A
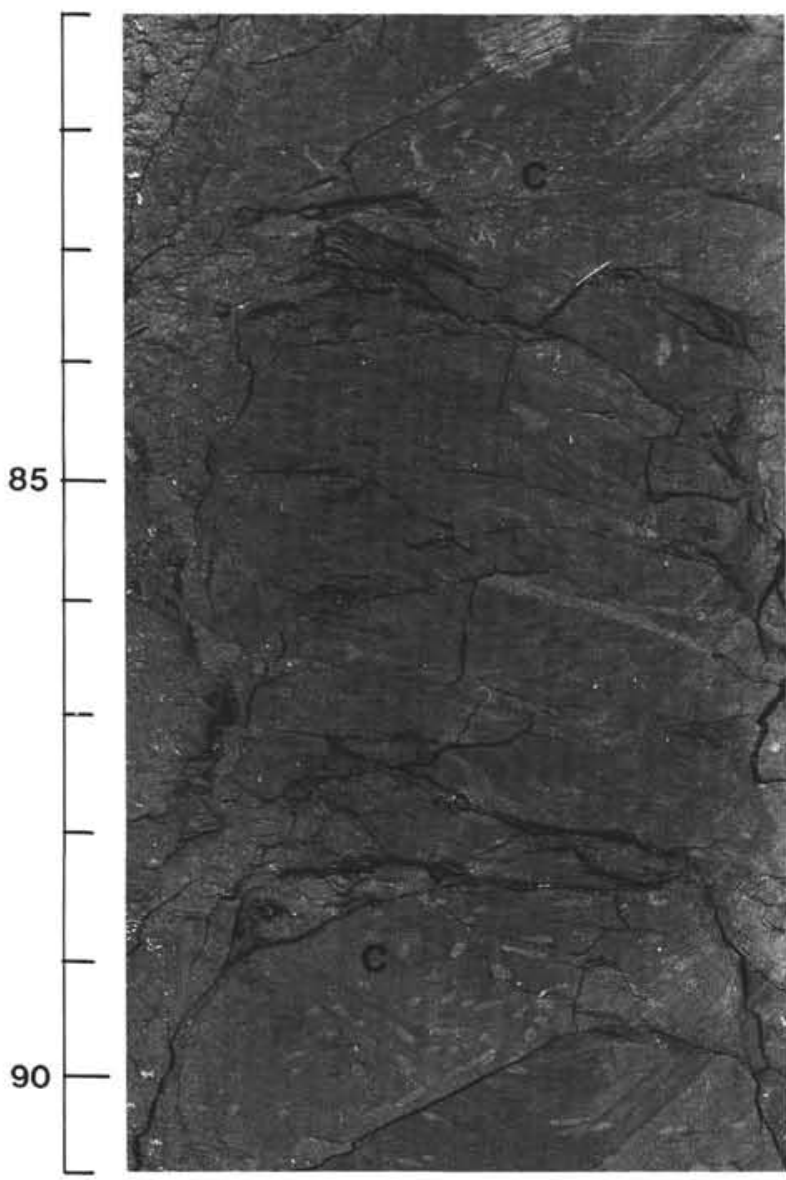

B

Figure 9. Bioturbation influenced by changing oxygenation of the bottom water. A. Sample 116-718C-94-1, 22-28 cm: Chondrites $(C)$ and small-sized, shallow-penetrating Zoophycos $(Z)$ indicate a low oxygenation level. The lower part of this section is laminated. Note compressed, previously open marginal tube of Zoophycos. B. Sample 116-717C-53-2, 81-91 cm: bioturbation by Chondrites $(C)$ only indicates a low oxygenation level. C. Sample 116-718C-64-2, 140-148 cm; an intermediate oxygenation level is indicated by large-sized Zoophycos (Z). Planolites (not marked). Chondrites $(C)$, and poorly visible Phycosiphon $(P)$. D. Sample 116-718C-94-5, 74-83 cm; a high oxygenation level can be deduced from a condensed bioturbated section containing a diverse, small-sized ichnofauna with Chondrites $(C)$. Planolites $(P l)$, Thalassinoides $(T)$, and Zoophycos $(Z)$. Only three tiers can be distinguished.

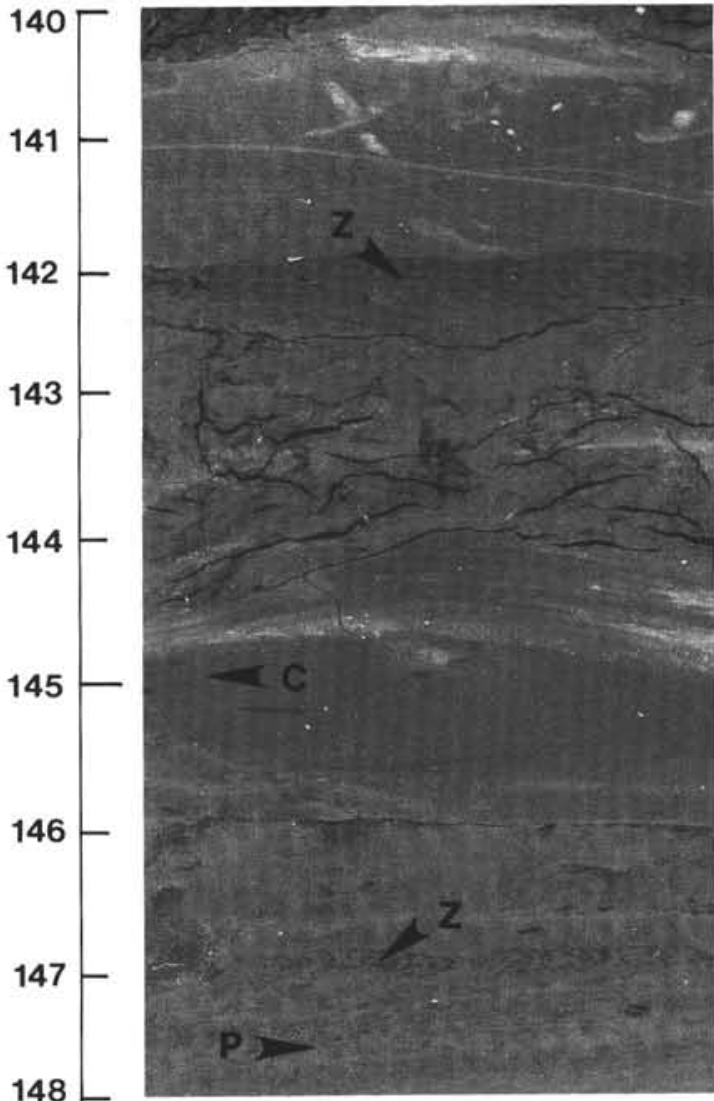

C

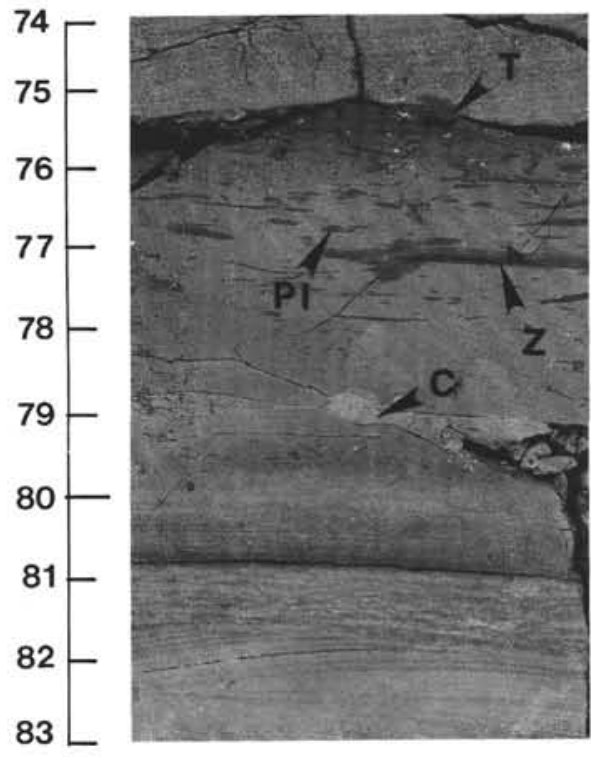




\section{ACKNOWLEDGMENT}

Financial support by the Deutsche Forschungsgemeinschaft to A. Wetzel is gratefully acknowledged.

\section{REFERENCES}

Basan, P. (Ed.), 1978. Trace Fossil Concepts. SEPM Short Course, 5.

Berger, W. H., Ekdale, A. A., and Bryant, P. P., 1979. Selective preservation of burrows in deep-sea carbonates. Mar. Geol., 32:205-230.

Bromley, R. G., and Ekdale, A. A., 1984. Chondrites: a trace fossil indicator of anoxia in sediments. Science, 224:872-874. 1986. Composite ichnofabrics and tiering in burrows. Geol. Mag., 123:59-65.

Chamberlain, C. K., 1978. Recognition of trace fossils in cores. In Basan, P. B. (Ed.), Trace Fossil Concepts. SEPM Short Course, 5:133-183.

Cochran, J. R., Stow, D.A.V., et al., 1989. Proc. ODP, Init. Repts.. 116: College Station, TX (Ocean Drilling Program).

Ekdale, A. A., 1985. Trace fossils and mid-Cretaceous anoxic events in the Atlantic Ocean. SEPM Spec. Publ., 35:333-342.

Ekdale, A. A., and Bromley, R. G., 1984. Sedimentology and ichnology of the Cretaceous-Tertiary boundary in Denmark: implications for the causes of the terminal Cretaceous extinctions. $J$. Paleontol., 54:681-703.

Ekdale, A. A., Bromley, R. G., and Pemberton, S. G. (Eds.), 1984. Ichnology. SEPM Short Course, 15.

Frey, R. W. (Ed.), 1975. The Study of Trace Fossils: Berlin (SpringerVerlag).

Häntzschel, W., 1965. Vestigia Invertebratorum et Problematica. Fossilium Catalogus Animalia pars 108: S'Gravenhage (W. Jung). 1975. Trace Fossils and Problematica (2nd ed.). In Teichert, C. (Ed.), Treatise on Invertebrate Paleontology, Part W. Miscellanea Supplement: Boulder (Geol. Soc. Am.) and Lawrence (Univ. Kansas).

Jumars, P. A., and Ekman. J. E., 1983. Spatial structure within deep-sea benthic communities. In Rowe, G. T. (Ed.), Deep-Sea Biology (Vol. 8): New York (Wiley), 399-451.

Kern, J. P., 1978. Paleoenvironment of new trace fossils from the Eocene Mission Valley Formation, California. J. Paleontol., 52:186-194.

Marintsch. E. J., and Finks, R. M., 1978. Zoophycos size may indicate environmental gradients. Lethaia, 11:273-279.

Pemberton, S. G., and Frey, R. W., 1982. Trace fossil nomenclature and the Planolites-Paleophycos dilemma. J. Paleontol., 56:843881.

Savrda, C. E., and Bottjer, D. J., 1986. Trace fossil model for reconstruction of paleo-oxygenation in bottom waters. Geology, 14:3-6.
Schäfer, W., 1956. Wirkungen der Benthos Organismen auf den jungen Schichtverband. Senckenbergiana, 37:183-263.

Seilacher, A., 1953. Studien zur Palichnologie. I. Über die Methoden der Palichnologie. Neues Jahrb. Geol. Palaeontol. Abh., 96:421451.

1962. Paleontological studiesin turbidite sedimentation and erosion. J. Geol., 70:227-234.

1967. Bathymetry of trace fossils. Mar. Geol., 5:413-428.

1977. Evolution of trace fossil communities. In Hallam, A. (Ed.), Patterns of Evolution: Amsterdam (Elsevier), 359-376.

Stow, D.A.V., and Piper, D.J.W., 1984. Deep-water fine-grained sediments: history methodology and terminology. In Stow, D.A.V., and Piper, D.J.W. (Eds.), Fine-Grained Sediments: Deep-Water Processes and Facies. Spec. Publ., Geol. Soc. London, 15:3-14.

Thiel, H., 1975. The size structure of the deep-sea benthos. Int. Rev. Gesamten Hydrobiol., 60:575-606.

1983. Mesobenthos and nanobenthos of the deep sea. In Rowe, G. T. (Ed.), Deep-Sea Biology (Vol. 8): New York (Wiley), $167-230$.

Werner, F., 1967. Röntgen-Radiographie zur Untersuchung von Sedimentstrukturen. Umschau, 16:532.

Werner, F., and Wetzel, A., 1982. Interpretation of biogenic structures in oceanic sediments. Bull. Inst. Geol. Bassin Aquitaine, 31:275-288.

Wetzel, A., 1981. Ökologische und stratigraphische Bedeutung biogener Gefüge in quartären Sedimenten am NW-afrikanischen Kontinentalrand. "Meteor" Forschungsergeb. Reihe C, 34:1-34. 1983. Biogenic sedimentary structures in a modern upwelling region: northwest African continental margin. In Thiede, J., and Suess, E. (Eds.), Coastal Upwelling: Its Sediment Record (Pt. B): New York (Plenum), 123-144.

1984. Bioturbation in deep-sea fine-grained sediments: influence of sediment texture, turbidite frequency and rates of environmental change. In Stow, D.A.V., and Piper, D.J.W. (Eds.), Fine-Grained Sediments: Deep Water Processes and Facies. Spec. Publ., Geol. Soc. London, 24:595-608.

1987. Ichnofabrics in Eocene to Maestrichtian sediments from Deep Sea Drilling Project Site 605, off the New Jersey Coast. In Van Hinte, J., Wise, S. W., Jr., et al., Init. Repts. DSDP, 93 (Pt. 2): Washington (U.S. Govt. Printing Office), 825-835.

Wetzel, A., and Werner, F., 1981. Morphology and ecological significance of Zoophycos in deep-sea sediments off NW Africa. Palaeogeogr., Palaeoclimatol., Palaeoecol., 32:185-212.

Wyrtki, K., 1971. Oceanographic Atlas of the International Ocean Expedition. Washington (NSF).

Date of initial receipt: 15 August 1988

Date of acceptance: 15 December 1989

Ms 116B-114 